\title{
Chromium immobilization by extraradical mycelium of arbuscular mycorrhiza contributes to plant chromium tolerance
}

\author{
Songlin $\mathrm{Wu}^{\mathrm{a}, \mathrm{b}}$, Xin Zhang ${ }^{\mathrm{a}}$, Baodong Chen ${ }^{\mathrm{a}, *}$, Zhaoxiang $\mathrm{Wu}^{\mathrm{a}, \mathrm{b}}$, Tao $\mathrm{Li}^{\mathrm{a}}$, Yajun $\mathrm{Hu}^{\mathrm{c}}$, \\ Yuqing Sun ${ }^{\mathrm{a}, \mathrm{b}}$, Youshan Wang ${ }^{\mathrm{d}}$ \\ a State Key Laboratory of Urban and Regional Ecology, Research Center for Eco-Environmental Sciences, Chinese Academy of Sciences, Beijing 100085, People's \\ Republic of China \\ ${ }^{\mathrm{b}}$ University of Chinese Academy of Sciences, Beijing 100049, People's Republic of China \\ ${ }^{\mathrm{c}}$ Key Laboratory of Agro-ecological Processes in Subtropical Region, Institute of Subtropical Agriculture, Chinese Academy of Sciences, Changsha 410125, \\ People's Republic of China \\ ${ }^{\mathrm{d}}$ Institute of Plant Nutrition and Resources, Beijing Academy of Agriculture and Forestry Sciences, Beijing 100097, People's Republic of China
}

\section{A R T I C L E I N F O}

\section{Article history:}

Received 24 May 2015

Received in revised form 27 July 2015

Accepted 22 August 2015

Available online 28 August 2015

\section{Keywords:}

Arbuscular mycorrhiza

Cr tolerance

Phosphorus

$\mathrm{Cr}$ immobilization

SR $\mu$-XRF

\begin{abstract}
A B S T R A C T
Arbuscular mycorrhizal (AM) fungi, as important plant mutualists, can protect host plants against environmental stresses, including heavy metal contaminations. It is generally accepted that improvement of plant P nutrition by AM symbiosis plays an important role in plant tolerance to heavy metals. In the present study, we tested if exogenous $\mathrm{P}$ amendment to the chromium ( $\mathrm{Cr}$ ) contaminated soil could match the positive effects of AM symbiosis on plant $\mathrm{Cr}$ tolerance for the highly mycorrhizal dependent plant-dandelion (Taraxacum platypecidum Diels.). Experimental results showed that $\mathrm{P}$ addition could not enhance plant growth as well as AM symbiosis did. AM fungi could immobilize $\mathrm{Cr}$ in mycorrhizal roots besides enhancing plant $\mathrm{P}$ acquisition. $\mathrm{Cr}$ distribution pattern in principal roots as revealed by synchrotron radiation micro-focused X-ray fluorescence (SR $\mu$-XRF) analysis supported the stabilization of $\mathrm{Cr}$ in mycorrrihzal roots. Furthermore, by using a three-compartment cultivation system, we demonstrated that extraradical mycelium (ERM) could take up and transport $\mathrm{Cr}$ to mycorrhizal roots, but restrained $\mathrm{Cr}$ translocation from roots to shoots, and thus contributed to $\mathrm{Cr}$ immobilization in roots and relieved $\mathrm{Cr}$ phytotoxicity.
\end{abstract}

(c) 2015 Elsevier B.V. All rights reserved.

\section{Introduction}

As the seventh most abundant element on earth, chromium $(\mathrm{Cr})$ is essential in glucose metabolism of human beings and animals (Katz and Salem, 1994; Shrivastava et al., 2002). By contrast, Cr is a non-essential element for plants, which can interfere with photosynthesis and respiration processes, lead to oxidative damage, inhibit important enzymatic activities, and even cause plant death (Shanker et al., 2005; Singh et al., 2013a). Naturally $\mathrm{Cr}$ has two stable forms, hexavalent chromium $[\mathrm{Cr}(\mathrm{VI})]$ and trivalent chromium [ $\mathrm{Cr}(\mathrm{III})]$, of which $\mathrm{Cr}(\mathrm{VI})$ is highly mobile, and more toxic than $\mathrm{Cr}$ (III) for its mutagenic and carcinogenic effects (Losi et al., 1994; Singh et al., 2013a). Chromium is widely used in the chemical industries such as electroplating, leather tanning, pigment production, etc. In the past decades, improper discharge of $\mathrm{Cr}$

\footnotetext{
* Corresponding author at: No 18, Shuangqing Road, Haidian District, Beijing 100085, People's Republic of China. Fax: +86 1062923549.

E-mail address: bdchen@rcees.ac.cn (B. Chen).
}

into environment during $\mathrm{Cr}$ processing has resulted in severe $\mathrm{Cr}$ contaminations, and subsequently threatened the ecosystem stability (Mohanty and Patra, 2011).

In the natural ecosystem, plants usually establish intimate contact with rhizosphere microorganisms, among which arbuscular mycorrhizal fungi (AMF) are most common and can form symbiotic associations with more than $80 \%$ terrestrial plants (Smith and Read, 2008). AMF obtain carbohydrates from their host plants and in return they provide plants with mineral nutrients such as phosphorus (P), nitrogen (N), etc (Smith and Read, 2008). Additionally, AMF can relieve plant drought stress (Li et al., 2014), protect host plants from pathogens (Singh et al., 2013b), improve soil structure (Rillig and Steinberg, 2002), and even play an important role in maintaining plant biodiversity and ecosystem stability (van der Heijden et al., 1998). Various studies have demonstrated that AM symbiosis take an active part in plant resistance to heavy metal contamination including $\mathrm{As}, \mathrm{Cd}, \mathrm{Cu}$ and Cr etc (Chen et al., 2007a,b, 2005; Davies et al., 2001; Wu et al., 2014). For example, Davies et al. (2001) found that AMF could enhance $\mathrm{Cr}$ tolerance of sunflower (Helianthus annuus) under $\mathrm{Cr}$ 
stress. Our recent work has also indicated that AM symbiosis could greatly enhance $\mathrm{Cr}$ tolerance of both dandelion (Taraxacum platypecidum Diels.) and bermudagrass (Cynodon dactylon (linn.) Pers.) under $\mathrm{Cr}(\mathrm{VI})$ contamination conditions (Wu et al., 2014).

Although AM symbiosis can protect host plants against $\mathrm{Cr}$ stress, little information is available as for the underlying mechanisms. One possible mechanism is that AM symbiosis can improve plant growth through enhancing plant $P$ uptake, which subsequently result in so-called "growth dilution effects" on metals in plants (Chen et al., 2007a). AMF is well known for its positive effects on plant $P$ nutrition especially under stressful conditions. For example, AM symbiosis substantially increased $\mathrm{P}$ uptake efficiency of dandelion plants under $\mathrm{Cr}(\mathrm{VI})$ contaminations (Wu et al., 2014). However, we do not know if this is the main way AM fungi enhance plant $\mathrm{Cr}(\mathrm{VI})$ tolerance, and if $\mathrm{AM}$ function can be replaced by exogenous $\mathrm{P}$ addition.

Another explanation for the alleviation of plant $\mathrm{Cr}$ toxicity by AM symbiosis is that the extensive extraradical mycelium (ERM) may directly immobilize large quantities of $\mathrm{Cr}$ and restrict its translocation from roots to plant shoots, just like Cd (Nayuki et al., 2014) and U (Weiersbye et al., 1999; Rufyikiri et al., 2002). ERM has a high cation exchange capacity (CEC) and can adsorb metals on fungal surface (Joner et al., 2000; Chen et al., 2001). Even if ERM can transport metals to mycorrhizal roots, the metals may not be actually delivered to plants across the symbiotic surface between AMF and root cells (Joner and Leyval, 1997; Nayuki et al., 2014). Therefore, the second question is that whether ERM can take up and retain $\mathrm{Cr}$ in plant roots, and thus relieve $\mathrm{Cr}$ phytotoxicity.

To address the above two questions, we carried out two experiments in which dandelion plants, together with AM fungusRhizophagus irregularis were adopted to establish mycorrhizal associations. In the first experiment, different $\mathrm{P}$ addition treatments, along with mycorrhizal inoculation treatments were arranged in $\mathrm{Cr}(\mathrm{VI})$ amended soils to investigate if AM fungi enhance plant $\mathrm{Cr}(\mathrm{VI})$ tolerance mainly through improving plant $\mathrm{P}$ acquisition, and whether AM function can be replaced by exogenous $\mathrm{P}$ addition. We predicted that AMF enhance plant $\mathrm{Cr}$ tolerance mainly through improving plant $\mathrm{P}$ nutrition, and appropriate $\mathrm{P}$ application would increase plant growth under $\mathrm{Cr}$ (VI) contamination as well as AM symbiosis did. In the second experiment, we used a compartment cultivation system to investigate if ERM can directly take up and transport $\mathrm{Cr}$ to plants, and also play an important role in $\mathrm{Cr}$ immobilization in mycorrhizal roots, which could potentially relieve $\mathrm{Cr}$ phytotoxicity.

\section{Material and methods}

\subsection{Growth substrate}

A calcareous sandy soil with low nutrient level was collected from Panggezhuang, Daxing district, Beijing ( $\left.39^{\circ} 36^{\prime} \mathrm{N}, 116^{\circ} 18^{\prime} \mathrm{E}\right)$. As analyzed by a laser diffraction technique using a Longbench Mastersizer 2000 (Malvern Instruments, Malvern, England), the soil consisted of $12.1 \%(\mathrm{v} / \mathrm{v})$ clay $(0-5 \mu \mathrm{m}), 51.7 \%(\mathrm{v} / \mathrm{v})$ silt (5$50 \mu \mathrm{m})$ and $36.2 \%(\mathrm{v} / \mathrm{v})$ sand $(50-2000 \mu \mathrm{m})$. Soil properties are described in details in Table S1. The soil was passed through a $2 \mathrm{~mm}$ sieve and then sterilized by radiation ( $\gamma$ rays, $20 \mathrm{kGy}, 10 \mathrm{MeV}$ electron beam). Before experiment, basal nutrients with $30 \mathrm{mg}$ $\mathrm{kg}^{-1} \mathrm{P}, 120 \mathrm{mg} \mathrm{kg}^{-1} \mathrm{~N}$ and $120 \mathrm{mg} \mathrm{kg}^{-1} \mathrm{~K}$ were carefully mixed into the soil.

\subsection{Host plant}

Based on our previous study (Wu et al., 2014), we used highly mycorrhizal dependent plant dandelion (Taraxacum platypecidum Diels.) as host plant. Seeds of dandelion were purchased from
Beijing Greatgreen Ecological Technology Development Company, Beijing, China. The seeds were surface sterilized with $10 \% \mathrm{H}_{2} \mathrm{O}_{2}$ for $15 \mathrm{~min}$, washed carefully with Milli-Q water, and then pregerminated on moist filter paper until the appearance of radicles.

\subsection{AM fungus}

The AM fungus Rhizophagus irregularis Schenck \& Smith (BGC AH01) were provided by Institute of Plant Nutrition and Resources, Beijing Academy of Agriculture and Forestry. The fungi were propagated on Sorghum bicolor (L.) Moench in a sandy soil for 12 weeks. Inoculum from the pot culture is a mixture of plant root fragments, mycelium, spores (c.a. 150 spores $\mathrm{g}^{-1}$ ) and sandy soil.

\subsection{Experimental procedure}

\subsubsection{Experiment I}

This experiment aimed to reveal the importance of plant $\mathrm{P}$ nutrition in plant $\mathrm{Cr}(\mathrm{VI})$ tolerance. The soils were amended with $10 \mathrm{mg} \mathrm{kg}^{-1} \mathrm{Cr}$ in the form of $\mathrm{K}_{2} \mathrm{CrO}_{4}[\mathrm{Cr}(\mathrm{VI})]$, and then carefully mixed to ensure uniformity. After that, the soil was placed for over a year to allow metal equilibrium. Phosphorus $(0,30,60$, $150 \mathrm{mg} \mathrm{kg}^{-1}$ ) in the form of $\mathrm{KH}_{2} \mathrm{PO}_{4}$ were added to the soil and carefully mixed for homogeneity. Besides, an AM inoculated treatment without $\mathrm{P}$ addition was arranged. Considering the main purpose of this experiment was to investigate if $\mathrm{P}$ amendment could relieve plant $\mathrm{Cr}(\mathrm{VI})$ toxicity in comparison with mycorrhizal treatment, it is unnecessary to detect mycorrhizal effects under each $P$ addition level. Thus, totally 5 treatments were arranged, namely "control", "P30", "P60", "P150" and "+M", where "P" represents phosphorus, "+M" represents mycorrhizal inoculation. Each treatments had 4 replicates, resulting in 20 pots in total.

For AM inoculated treatment ("+M"), $300 \mathrm{~g} \mathrm{Cr}(\mathrm{VI})$ contaminated soil was firstly put into the pot, and then $300 \mathrm{~g} \mathrm{Cr}(\mathrm{VI})$ contaminated soil that contained $30 \mathrm{~g}$ fungal inoculum was added. As for noninoculated treatment at each $\mathrm{P}$ addition level, $30 \mathrm{~g}$ sterilized inoculum and $10 \mathrm{~mL}$ inoculum filtrate (passed through a $15 \mu \mathrm{m}$ filter to remove AMF) was added instead to reintroduce soil microbial communities except AMF. Each pot was sown with 10 pre-germinated dandelion seeds. 10 days after emergence seedlings were thinned to 2 per pot, and each pot was daily watered with deionized water to maintain moisture content of $15 \%$ on a dry weight basis (around 55\% of water holding capacity). The experiment was conducted in a controlled growth chamber at a light intensity of $700 \mu \mathrm{mol} \mathrm{m}{ }^{-2} \mathrm{~s}^{-1}, 16 \mathrm{~h}: 8 \mathrm{~h}$ and $25^{\circ} \mathrm{C}: 20^{\circ} \mathrm{C}$ (light: dark), 70\% relative humidity. The plants grew for 2 months before experimental harvest.

\subsubsection{Experiment II}

This experiment aimed to exploit whether ERM could take up and transport $\mathrm{Cr}$ to plants. A compartment cultivation system was used, which was a rectangular box $(12 \mathrm{~cm}$ high, $14 \mathrm{~cm}$ wide and $10 \mathrm{~cm}$ deep) with three compartments: a root compartment (RC) at one side of $8 \mathrm{~cm}$ width, a hyphal compartment (HC) at the other side of $4 \mathrm{~cm}$ width, and a central buffer compartment (BC) of $2 \mathrm{~cm}$ width (Fig. 1). All three compartments were separated by a $37 \mu \mathrm{m}$ nylon net that only allow penetration by hyphae but not by roots. RC was set for plant growth, HC was set for extraradical mycelium development, and $\mathrm{BC}$ for avoiding $\mathrm{Cr}$ diffusion from $\mathrm{HC}$ to $\mathrm{RC}$. There were no $\mathrm{Cr}(\mathrm{VI})$ addition for RC and BC, while for $\mathrm{HC}, 60 \mathrm{mg} \mathrm{kg}^{-1} \mathrm{Cr}$ (VI) or no $\mathrm{Cr}(\mathrm{VI})$ was added. Four treatments were arranged in the present work, namely " $-\mathrm{M}+\mathrm{Cr}$ ", “+M+Cr”, “+M-Cr", "+M+F+ $\mathrm{Cr}$ ". For treatment " $+\mathrm{M}+\mathrm{Cr}$ ", dandelion in association with $\mathrm{AM}$ fungi was introduced to $\mathrm{RC}$ using the methods described in experiment I (but the total soil was $1 \mathrm{~kg}$ ), and $500 \mathrm{~g}$ soil with $60 \mathrm{mg} \mathrm{kg}^{-1} \mathrm{Cr}(\mathrm{VI})$ were added in $\mathrm{HC}$ and carefully mixed to ensure 


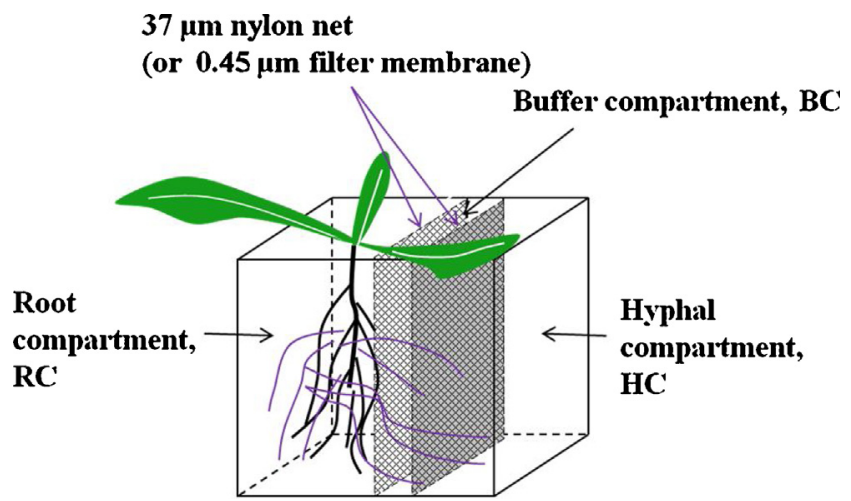

Fig. 1. Diagram of the three-compartment cultivation system in experiment II. Nylon net (or $0.45 \mu \mathrm{m}$ filter membrane) was used to separate the cultivation system into 3 compartments: root compartment $(\mathrm{RC})$ for plant growth, buffer compartment (BC), and hyphal compartment (HC) for hyphal development only. BC was set to avoid $\mathrm{Cr}$ diffusion from $\mathrm{HC}$ to $\mathrm{RC}$. $37 \mu \mathrm{m}$ Nylon net only permits ERM to penetrate but not for roots, while $0.45 \mu \mathrm{m}$ filter membrane does not permit penetration of ERM and roots.

uniformity, and $250 \mathrm{~g}$ soil without $\mathrm{Cr}$ contamination was put into BC. Compared with treatment " $+\mathrm{M}+\mathrm{Cr}$ ", treatment " $-\mathrm{M}+\mathrm{Cr}$ " had no AMF inoculation in $\mathrm{RC}$, treatment " $+\mathrm{M}-\mathrm{Cr}$ " had no $\mathrm{Cr}(\mathrm{VI})$ addition in $\mathrm{HC}$, treatment " $+\mathrm{M}+\mathrm{F}+\mathrm{Cr}$ " had a $0.45 \mu \mathrm{m}$ acetate filter membrane that can block ERM and roots to develop in HC instead of $37 \mu \mathrm{m}$ nylon net (Fig. 1). By such an experimental design, it is possible to control other factors except ERM that potentially contribute to $\mathrm{Cr}$ transport, and thus to confirm whether ERM can take up and translocate $\mathrm{Cr}$ to plant roots. Each treatment had 4 replicates, resulting in a total of 16 pots. Plant growth conditions were the same to experiment I. The plants grew for 80 days before experimental harvest.

\subsection{Harvest and sample analysis}

\subsubsection{Plant harvest}

Plant shoots and roots were harvested separately and washed carefully with deionized water. Sub-samples of fresh roots were collected for the determination of AM colonization. Parts of fresh principal roots were also collected for $\mathrm{Cr}$ mapping using synchrotron radiation micro-focused X-ray fluorescence (SR $\mu$-XRF) microspectroscopy. Dry weights of shoots and roots were determined after oven-drying at $70^{\circ} \mathrm{C}$ for $48 \mathrm{~h}$.

\subsection{2. $S R \mu-X R F$ analyses}

Fresh principal root samples at similar developmental stages were selected from both inoculated and noninoculated plants in experiment I where plant roots were exposed to $\mathrm{Cr}(\mathrm{VI})$ contamination. Principal roots were embedded by optimum cutting temperature (O.C.T.) compound (Sakura, Japan) and cut to sections of $40 \mu \mathrm{m}$ thick with a cryotome (CM1850, LEICA, Germany) at $-25^{\circ} \mathrm{C}$, and then adhered to $3 \mathrm{M}$ tape (cat. 810, Minnesota Mining and Manufacturing Company, Minn., USA). Sections in good conditions were selected for SR $\mu$-XRF analysis after being freeze-dried at $-25^{\circ} \mathrm{C}$ for $72 \mathrm{~h}$. The SR $\mu$-XRF microspectroscopy experiment was conducted at beamline 4W1B of Beijing Synchrotron Radiation Facility (BSRF), which runs $2.5 \mathrm{GeV}$ electron with current from $150 \mathrm{~mA}$ to $250 \mathrm{~mA}$. The detection limit for analysis was in the order of $\mathrm{mg} \mathrm{kg}^{-1}$. The incident X-ray energy was monochromatized by W/B4C double-multilayer-monochromator (DMM) at $15 \mathrm{keV}$ and was focused on an area of $50 \mu \mathrm{m}$ in diameter by the polycapillary lens. The two-dimensional mapping data were acquired by using a step size of $50 \mu \mathrm{m}$. The $\mathrm{Si}$ (Li) solid state detector was used to detect X-ray fluorescence emission lines with live time of $20 \mathrm{~s}$. SR $\mu$-XRF spectra were processed by the PyMCA software package (Solé et al., 2007).

\subsubsection{Plant $P$ and $C r$ concentrations}

Oven dried plant samples were milled and digested by $\mathrm{HNO}_{3}$ with a microwave accelerated reaction system (Mars 5, CEM Co., Ltd., USA) in a three-step digestion program: the temperature was raised to $120^{\circ} \mathrm{C}$ in $8 \mathrm{~min}$, holding for $3 \mathrm{~min}$; and then raised to $160^{\circ} \mathrm{C}$ in $11 \mathrm{~min}$, holding for $7 \mathrm{~min}$; and finally to $190^{\circ} \mathrm{C}$ in $8 \mathrm{~min}$ with holding time of $20 \mathrm{~min}$. The dissolved samples were then heated for additional $2 \mathrm{~h}$ at $140{ }^{\circ} \mathrm{C}$ to remove $\mathrm{NO}_{x}$. The final digestion solutions were diluted to $50 \mathrm{~mL}$ with Milli-Q water. P concentrations were analyzed by inductively coupled plasmaoptical emission spectrometer (ICP-OES, Prodigy, Leemans, USA), and $\mathrm{Cr}$ concentrations were determined by inductively coupled plasma-mass spectrometry (ICP-MS, 7500a Agilent Technologies, USA). Blanks and internal standards of bush leaves (GBW07603, China Standard Research Center) and tea (GBW10016, China Standard Research Center) were used to ensure the accuracy of chemical analysis.

\subsubsection{AM colonization}

Sub-samples of fresh roots were cut into approximately $1 \mathrm{~cm}$ fragments, cleared in $10 \% \mathrm{KOH}$ at $90^{\circ} \mathrm{C}$ for $1 \mathrm{~h}$, and then rinsed in $5 \%$ $\mathrm{HCl}$ for $5 \mathrm{~min}$, and stained with $0.05 \%$ Trypan blue at $90^{\circ} \mathrm{C}$ in water bath for $30 \mathrm{~min}$, which was in accordance with a modified procedure of Phillips and Hayman (1970) by omitting phenol from the rinse. Thirty pieces of randomly selected stained roots were observed with a light microscope and the intensity of AMF colonization was assessed by the method described by Trouvelot et al. (1986) by using MYCOCALC software (www2.dijon.inra.fr/ mychintec/Mycocalc-prg/download). The parameters measured included the frequency of mycorrhizal colonization (F\%, the ratio of the number of root fragments colonized by AMF to the total number of root fragments analyzed), the intensity of the mycorrhizal colonization ( $\mathrm{M} \%$, an estimate of the percentage of AM fungal structures in the whole root system) and the arbuscule abundance in the root system ( $\mathrm{A} \%$, an estimate of the percentage of arbuscule occurrence in the whole root system), etc.

\subsubsection{Soil hyphal length density}

ERM in RC and HC were extracted from soil samples using a modified membrane filter technique (Jakobsen et al., 1992). Briefly, the soil samples were mixed and $4 \mathrm{~g}$ of the samples were blended with $250 \mathrm{~mL}$ deionized water, hyphae in $5 \mathrm{~mL}$ aliquots were then collected on $25 \mathrm{~mm}$ membrane filters $(0.22 \mu \mathrm{m})$ and stained with $0.05 \%$ Trypan blue. Hyphal length density was determined by measuring intersections between blue-stained hyphae and the grids in the eyepiece in 25 fields of view at $\times 200$ magnification and then calculated by the modified Newman formula (Tennant, 1975).

\subsubsection{Soil Cr speciation}

Soil $\mathrm{Cr}(\mathrm{VI})$, DTPA-extractable $\mathrm{Cr}$, acid-extractable $\mathrm{Cr}$ and reducible $\mathrm{Cr}$ in $\mathrm{RC}, \mathrm{BC}$ and $\mathrm{HC}$ of different treatments were determined. Briefly, soil $\mathrm{Cr}(\mathrm{VI})$ concentrations were determined according to EPA method 3060A (USEPA, 1996), DTPA-extractable $\mathrm{Cr}$ concentrations were determined by using ICP-OES after extracting $\mathrm{Cr}$ from soil by $0.005 \mathrm{M}$ DTPA-0.01 $\mathrm{M} \mathrm{CaCl}_{2}-0.1 \mathrm{M}$ triethanolamine (TEA) solution ( $\mathrm{pH} 7.30)$ (Lindsay and Norvell, 1978), acid-extractable and reducible $\mathrm{Cr}$ were extracted separately by $0.11 \mathrm{~mol} / \mathrm{L}$ acetic acid and $0.5 \mathrm{~mol} / \mathrm{L}$ hydroxylammonium chloride according to European community bureau of reference (BCR) three-step sequential extraction procedure (Rauret et al., 2000), and then analyzed by ICP-OES. 


\subsection{Statistics analyses}

The translocation factor (TF), which represents the elemental translocation efficiency of plants, is expressed as the ratio of shoot $\mathrm{Cr}$ (or P) concentration to root $\mathrm{Cr}$ (or P) concentration (Tappero et al., 2007). All data were analyzed by one-way analysis of variance (ANOVA), followed by Duncan's test $(p<0.05)$ to determine the significance of differences between treatments.

\section{Results}

\subsection{Experiment I}

Similar to our previous study (Wu et al., 2014), inoculated plants showed very high frequency (100\%) and intensity (81.5\%) of mycorrhizal colonization, together with high arbuscule abundance (71.8\%) regardless of $\mathrm{Cr}(\mathrm{VI})$ contamination, while non-inoculated plants remained uncolonized (Table 1). Fig. S1 displays the morphological comparison between mycorrhizal and nonmycorrhizal roots. The mycorrhizal roots exhibited numerous arbuscules and intraradical mycelium, as well as vesicles (Fig. S1). By contrast, there was no typical fungal structures in nonmycorrhizal roots (Fig. S1).

In general, P addition had no significant influence on plant shoot and root dry weights (Fig. 2a and b), while mycorrhizal colonization dramatically increased plant shoot dry weights (Fig. 2a, $p<0.05$ ). Both AM colonization and P addition level of $150 \mathrm{mg} \mathrm{kg}^{-1}$ increased plant shoot $\mathrm{P}$ concentration (Fig. 2c, $p<0.05$ ), while $\mathrm{P}$ addition and AMF inoculation did not influence plant root $P$ concentration (Fig. 2d).

Both $\mathrm{P}$ addition and AMF inoculation decreased plant root $\mathrm{Cr}$ concentration, but only AM symbiosis significantly decreased shoot $\mathrm{Cr}$ concentration (Fig. 2e and $\mathrm{f}, p<0.05$ ). When plant $\mathrm{P}$ or $\mathrm{Cr}$ translocation factor (TF) were considered, $150 \mathrm{mg} \mathrm{kg}^{-1} \mathrm{P}$ addition significantly increased TF value for $\mathrm{P}$ (Fig. 3a, $p<0.05$ ). However, $\mathrm{P}$ addition did not affect $\mathrm{TF}$ value for $\mathrm{Cr}$, while $\mathrm{AM}$ colonization significantly decreased $\mathrm{Cr}$ TF value (Fig. $3 \mathrm{~b}, p<0.05$ ).

By SR $\mu$-XRF analysis, we found that mycorrhizal colonization changed $\mathrm{Cr}$ distribution in roots, as compared with non-mycorrhizal roots where $\mathrm{Cr}$ signal was detected both in the cortex and vascular bundle, $\mathrm{Cr}$ signal was detected only in the cortex of mycorrhizal principal roots (Fig. 4). While for other elements such as $\mathrm{Ca}, \mathrm{K}, \mathrm{Fe}, \mathrm{Cu}$ and $\mathrm{Zn}, \mathrm{AMF}$ inoculation had no influence on their distribution. For both mycorrhizal and non-mycorrhizal principal roots, $\mathrm{Ca}$, $\mathrm{K}$ and Fe were mainly located in the cortex, while $\mathrm{Cu}$ and $\mathrm{Zn}$ were detected both in the cortex and the vascular bundles (Fig. 4).

\section{Table 1}

Mycorrhiza development parameters in roots of dandelion (Taraxacum platypeci$\mathrm{dum}$ ) grown in $10 \mathrm{mg} \mathrm{kg}^{-1} \mathrm{Cr}(\mathrm{VI})$ contaminated soils with different phosphate $(\mathrm{P})$ additions and mycorrhizal inoculation (experiment I). Values are mean $\pm \operatorname{SD}(n=4)$. Means followed by the same letter are not significantly different (Duncan test, $p<0.05$ ).

\begin{tabular}{llll}
\hline Treatment & $\mathrm{F}(\%)^{\mathrm{f}}$ & $\mathrm{M}(\%)^{\mathrm{g}}$ & $\mathrm{A}(\%)^{\mathrm{h}}$ \\
\hline Control $^{\mathrm{a}}$ & $9.64 \pm 3.79 \mathrm{~b}$ & $1.21 \pm 0.91 \mathrm{~b}$ & $0.12 \pm 0.09 \mathrm{~b}$ \\
$\mathrm{P}^{\mathrm{b}} \mathrm{b}^{\mathrm{C}}$ & $6.91 \pm 0.35 \mathrm{~b}$ & $1.35 \pm 0.28 \mathrm{~b}$ & $0.14 \pm 0.03 \mathrm{~b}$ \\
$\mathrm{P}^{\mathrm{c}}$ & $8.84 \pm 3.14 \mathrm{~b}$ & $0.80 \pm 0.81 \mathrm{~b}$ & $0.08 \pm 0.08 \mathrm{~b}$ \\
$\mathrm{P}^{5} 0^{\mathrm{d}}$ & $3.71 \pm 5.23 \mathrm{~b}$ & $1.27 \pm 1.81 \mathrm{~b}$ & $0.13 \pm 0.18 \mathrm{~b}$ \\
$+\mathrm{M}^{\mathrm{e}}$ & $100 \pm 0 \mathrm{a}$ & $81.5 \pm 2.93 \mathrm{a}$ & $71.8 \pm 5.51 \mathrm{a}$ \\
\hline
\end{tabular}

a Control: no P amendment, without mycorrhizal inoculation.

b P30: P amendment of $30 \mathrm{mg} \mathrm{kg}^{-1}$, without mycorrhizal inoculation.

c P60: P amendment of $60 \mathrm{mg} \mathrm{kg}^{-1}$, without mycorrhizal inoculation.

d P150: P amendment of $150 \mathrm{mg} \mathrm{kg}^{-1}$, without mycorrhizal inoculation.

e +M: no P amendment, with mycorrhizal inoculation.

${ }^{\mathrm{f}} \mathrm{F}(\%)$ represents the frequency of mycorrhizal colonization.

${ }^{g} \mathrm{M}(\%)$ represents the intensity of the mycorrhizal colonization.

h $\mathrm{A}(\%)$ represents the arbuscule abundance.

\subsection{Experiment II}

Similar with experiment I, AM symbiosis developed well in mycorrhizal roots as mycorrhizal colonization frequency ( $\mathrm{F} \%$ ) was approximately $100 \%$, the intensity of colonization (M\%) exceeded $60 \%$, and the arbuscule abundance (A\%) were generally higher than $49 \%$ (Table 2). Besides, there were no difference in $\mathrm{F} \%, \mathrm{M} \%$ and $\mathrm{A} \%$ among all three inoculated treatments (Table 2, $p<0.05$ ). By contrast, no mycorrhizal colonization was detected in noninoculated plants (Table 2). AMF inoculation treatments also exhibited higher hyphal length densities in RC than that of noninoculation treatment (Table $2, p<0.05$ ). Treatments " $+\mathrm{M}+\mathrm{Cr}$ " and "+M $-\mathrm{Cr}$ " had higher hyphal length densities in $\mathrm{HC}$ than treatments " $-\mathrm{M}+\mathrm{Cr}$ " and "+M+F+Cr" (Table 2, $p<0.05$ ).

Generally, AM colonization increased plant shoot and root dry weights except for treatment " $+\mathrm{M}-\mathrm{Cr}$ " (Fig. 5a and b, $p<0.05$ ), and there were no significant differences in plant dry weights among the three inoculated treatments (Fig. 5a and b). AM colonization increased plant $\mathrm{P}$ concentrations especially for roots, while decreased shoot $\mathrm{Cr}$ concentration significantly (Fig. 5c-f, $p<0.05$ ). The treatment " $+\mathrm{M}+\mathrm{Cr}$ " had a higher root $\mathrm{Cr}$ concentration than other three control treatments (Fig. $5 \mathrm{f}, p<0.05$ ), and root Cr concentration of " $+\mathrm{M}-\mathrm{Cr}$ " was lower than that of " $-\mathrm{M}+\mathrm{Cr}$ " and "+M + F+ Cr" (Fig. 5f, $p<0.05$ ). Among all 4 treatments, " $+\mathrm{M}+\mathrm{Cr}$ " held the highest root and total $\mathrm{Cr}$ uptake (Fig. S2, $p<0.05$ ), while there was no difference in shoot $\mathrm{Cr}$ uptake. Besides, treatment "+M + Cr" had the lowest TF value for Cr of all 4 treatments (Fig. S3).

\section{Discussions}

Through comparing the influences of exogenous P amendment with $\mathrm{AM}$ symbiosis on plant $\mathrm{Cr}(\mathrm{VI})$ tolerance, the present study revealed that $\mathrm{AM}$ symbiosis was multifunctional, and its benefits for host plants could not be simply replaced by $\mathrm{P}$ amendment. Furthermore, many previous studies (Chen et al., 2001, 2003, 2007b; Wu et al., 2014) implied the significance of metal immobilization by AM fungi in plant metal tolerance. Therefore, SR $\mu$-XRF study on principal roots was carried out to test this possibility, and a compartment cultivation system was used to test if the extensive ERM contributed to $\mathrm{Cr}$ stabilization.

As one of the most important nutrients in plants, $\mathrm{P}$ is crucial for plant growth, development and reproduction. P also plays an important role in plant resistance to environmental stresses. For example, our recent study found that $\mathrm{P}$ addition improved the growth of Medicago truncatula L. under As contaminations (Zhang et al., 2015). However, the present study showed no significant improvement of plant growth by $\mathrm{P}$ addition in $\mathrm{Cr}(\mathrm{VI})$ contaminated soil, although certain P amendment level ( $150 \mathrm{mg} \mathrm{kg}^{-1}$ ) increased shoot $\mathrm{P}$ concentration while decreased root $\mathrm{Cr}$ concentration (Fig. 2). The decreased $\mathrm{Cr}$ concentration may result from competition for root surface site between $\mathrm{Cr}(\mathrm{VI})$ and $\mathrm{P}$ (Chatterjee and Chatterjee 2000), as we previously found that $\mathrm{Cr}(\mathrm{VI})$ addition could decrease plant P concentration (Wu et al., 2014), and Qian's study (Qian et al., 2013) also showed that high Paddition decreased plant $\mathrm{Cr}$ absorption.

The fact that $P$ addition failed to promote plant growth might be caused by several reasons. Firstly, soil available $P$ might be sufficient for non-mycorrhizal dandelion under experimental conditions as can be seen from the control treatment that plant shoot and root $\mathrm{P}$ concentration was $1.92 \mathrm{mg} \mathrm{g}^{-1}$ and $1.88 \mathrm{mgg}^{-1}$, which were much higher than that in our previous study (Wu et al., 2014) under the same $\mathrm{Cr}(\mathrm{VI})$ contamination level (Fig. 2). Accordingly, P amendment (below $60 \mathrm{mg} \mathrm{kg}^{-1}$ ) did not increase plant $\mathrm{P}$ acquisition (Fig. 2). Although $150 \mathrm{mg} \mathrm{kg}^{-1} \mathrm{P}$ amendment did increase shoot $P$ concentration, it did not affect plant growth probably because of excessive P uptake. Secondly, it is well known 

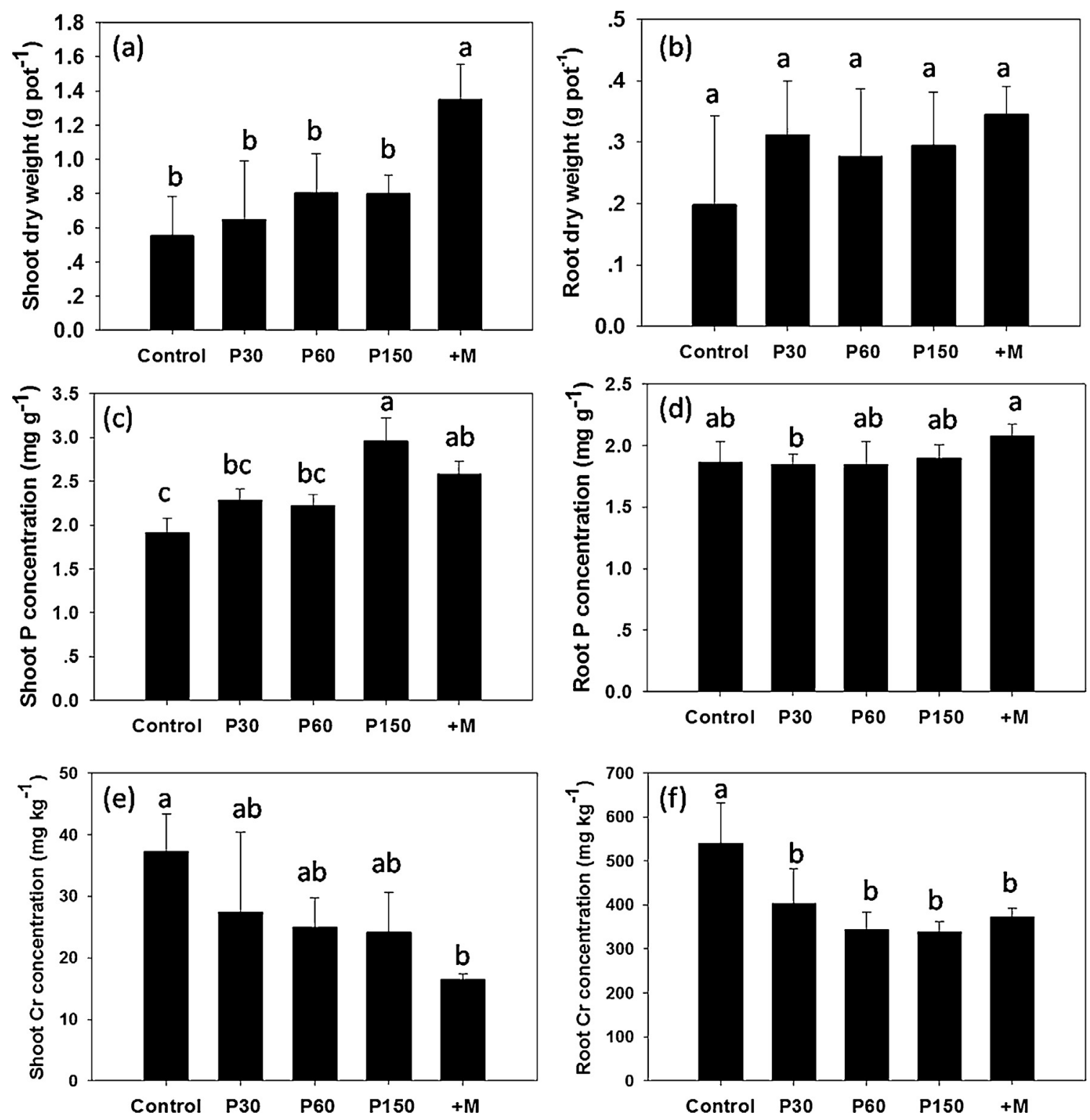

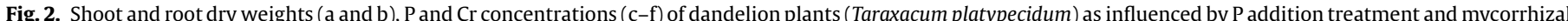

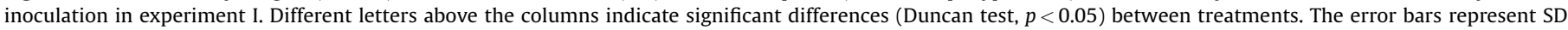

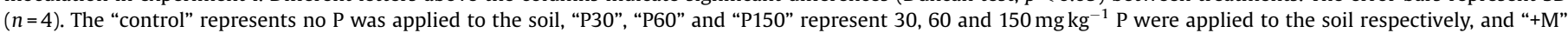
represents mycorrhizal inoculation without $\mathrm{P}$ application to the soil.

that soil phosphatases play an important role in $\mathrm{P}$ uptake by plants and mycorrhizal fungi, as these enzymes can mineralize organic $P$ to inorganic P (Nannipieri et al., 2011), and therefore take an active part in $\mathrm{P}$ uptake by plants and mycorrhizal fungi. $\mathrm{Cr}$ contamination could possibly reduce soil phosphatase activities and thus decrease plant P uptake (Tyler, 1974; Kuperman and Carreiro, 1997). The decreased activities of soil phosphatases caused by $\mathrm{Cr}$ contamination probably could not be compensated by $\mathrm{P}$ application as previous study showed an inverse relation between P supply and acid phosphatase activity in soil (Spiers and McGill, 1979). However, AM symbiosis could possibly increase soil phosphatase activities under heavy metal contaminations (Wang et al., 2006), which would be beneficial for plant $\mathrm{P}$ acquisition. Thirdly, there may be different strategies for $\mathrm{P}$ absorption and translocation between non-mycorrhizal and mycorrhizal plants. AM symbiosis can mobilize $P$ in the soil, or directly take up and transport $P$ to plants (Feng et al., 2003; Karandashov and Bucher, 2005), while non-mycorrhizal root can only absorb mobile $\mathrm{P}$ in the soil
(Schachtman et al., 1998). Moreover, P in the mycelium mainly exists in the form of polyphosphate (poly P) (Kuga et al., 2008) and its transfer across the symbiotic interface is regulated by mycorrhiza-specific phosphate transporters (Karandashov and Bucher, 2005), while in the non-mycorrhizal roots there is no such regulation. The specific strategies of $P$ uptake, transport and conservation in mycorrhizal plants could maintain a better $\mathrm{P}$ homeostasis than that of non-mycorrhizal plants. Lastly, AM symbiosis could immobilize $\mathrm{Cr}$ in roots and reduce its translocation to shoots, which was indicated by lower $\mathrm{Cr}$ TF value of mycorrhizal plants compared with that of control treatment, while exogenous $\mathrm{P}$ did not show such effects (Fig. 3).

The depression of $\mathrm{Cr}$ transport from roots to shoots by AM symbiosis was also proved by SR $\mu$-XRF study on principal roots exposed to $\mathrm{Cr}(\mathrm{VI})$. Compared with non-mycorrhizal roots, where $\mathrm{Cr}$ was detected both in the cortex and vascular bundles, $\mathrm{Cr}$ was detected only in the cortex of mycorrhizal principal roots (Fig. 4). As $\mathrm{Cr}$ was mainly transported in the xylem (Skeffington et al., 

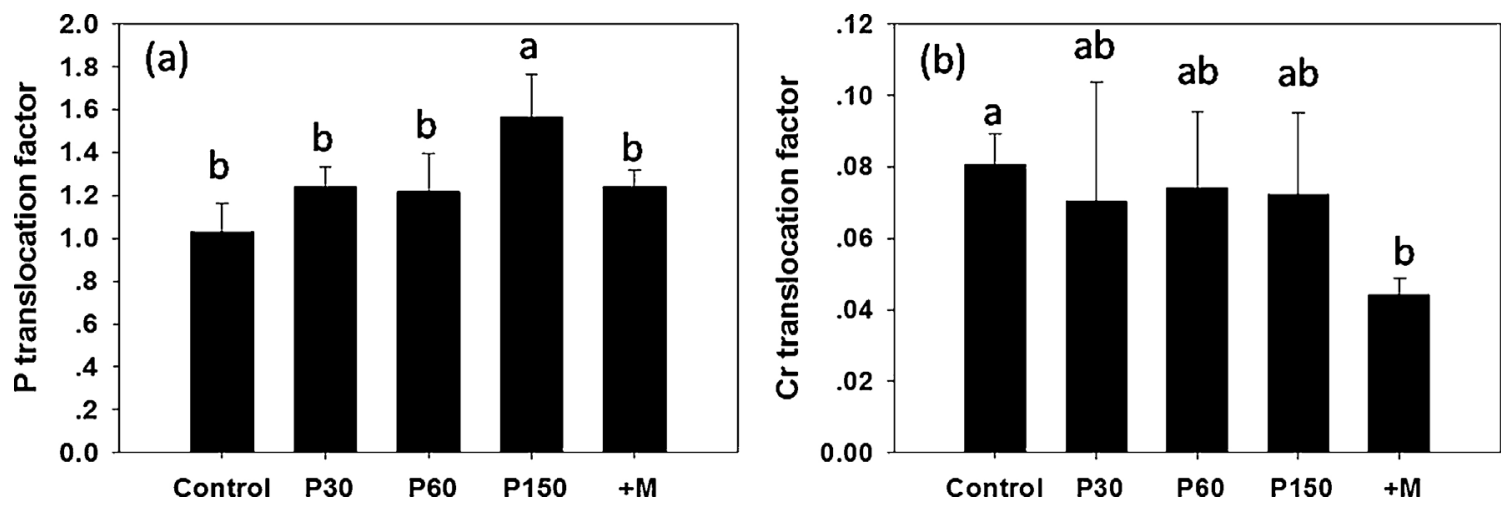

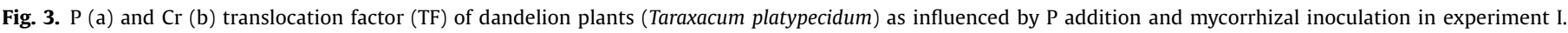

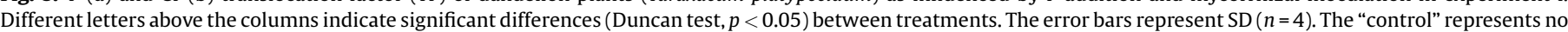

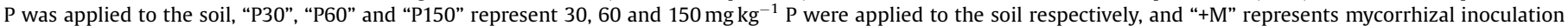
without P application to the soil.
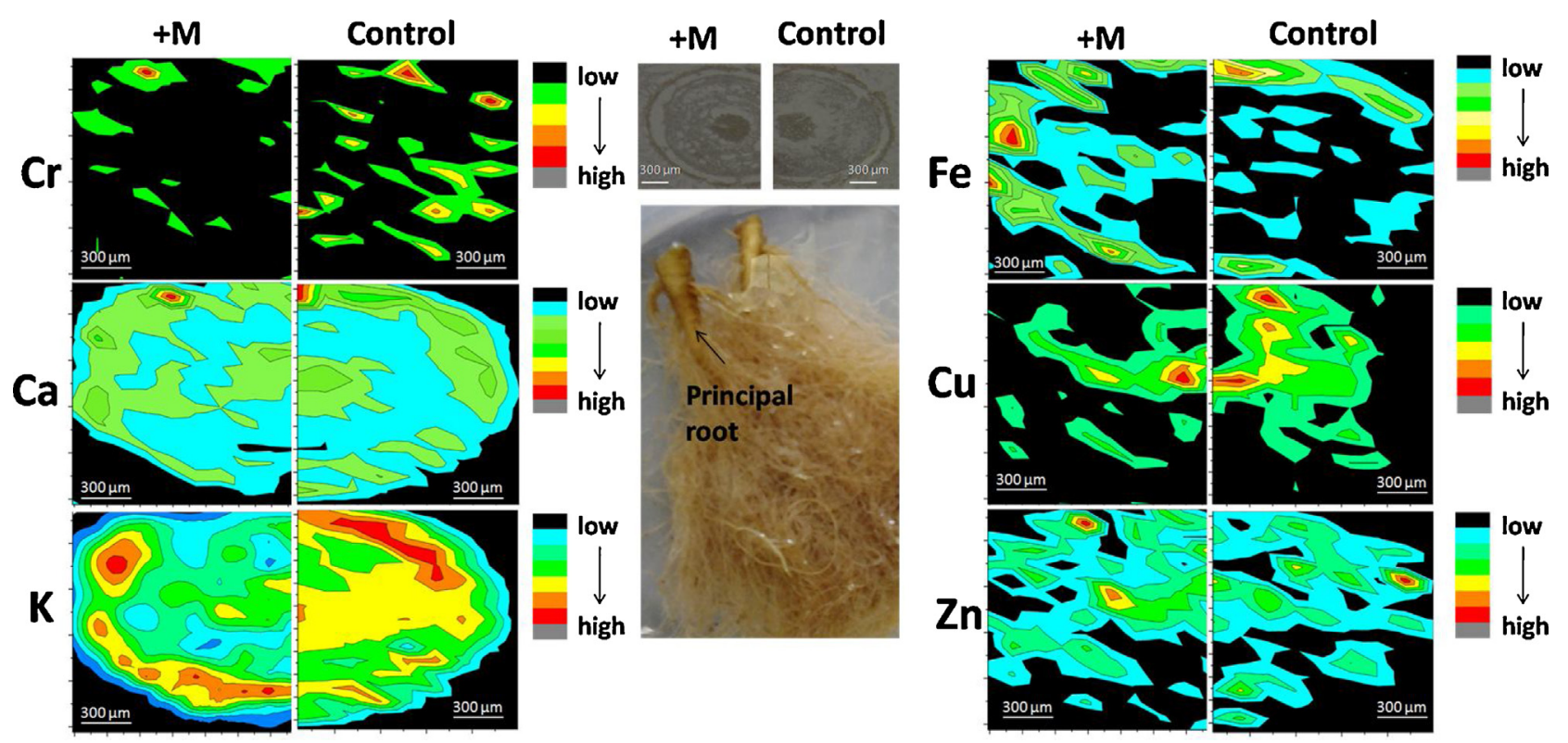

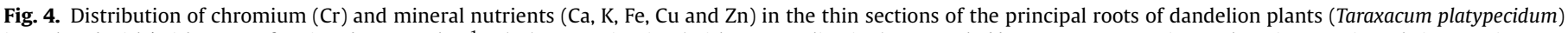

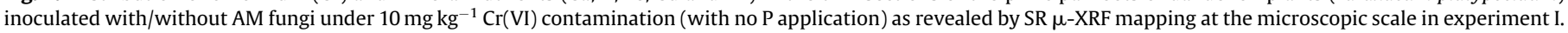
Pixel size is $50 \mu \mathrm{m}$.

1976), so the undetectable $\mathrm{Cr}$ in vascular bundle (including xylem) of principal root for mycorrhizal plants might indicate that large quantities of $\mathrm{Cr}$ were retained in highly colonized fibrous roots, and little $\mathrm{Cr}$ could be translocated to aboveground parts. As for other

\section{Table 2}

Mycorrhiza development parameters and hyphal length density of dandelion (Taraxacum platypecidum) inoculated with Rhizophagus irregularis as influenced by different compartmentation (experiment II). Values are mean $\pm \mathrm{SD}(n=4)$. Means followed by the same letter are not significantly different (Duncan test, $p<0.05$ ).

\begin{tabular}{lcccc}
\hline Treatment & $\mathrm{F}(\%)^{\mathrm{e}}$ & $\mathrm{M}(\%)^{\mathrm{f}}$ & $\mathrm{A}(\%)^{\mathrm{g}}$ & Hyphal length density $\left(\mathrm{mg} \mathrm{g}^{-1}\right)$ \\
\cline { 3 - 4 } & & & $0.46 \pm 0.16 \mathrm{~b}$ \\
$\mathrm{RC}^{\mathrm{h}}$ & 0 & $2.35 \pm 0.69 \mathrm{a}$ \\
$+\mathrm{M}+\mathrm{Cr}^{\mathrm{a}}$ & 0 & 0 & $52.6 \pm 11.8 \mathrm{a}$ & $0.38 \pm 0.15 \mathrm{c}$ \\
$+\mathrm{M}+\mathrm{Cr}^{\mathrm{b}}$ & $100 \pm 0 \mathrm{a}$ & $66.6 \pm 7.57 \mathrm{a}$ & $49.7 \pm 12.6 \mathrm{a}$ & $1.76 \pm 0.52 \mathrm{a}$ \\
$+\mathrm{M}+\mathrm{F}+\mathrm{Cr}^{\mathrm{d}}$ & $99.2 \pm 1.66 \mathrm{a}$ & $62.6 \pm 14.2 \mathrm{a}$ & $66.4 \pm 12.3 \mathrm{a}$ & $2.22 \pm 0.71 \mathrm{a}$ \\
\hline
\end{tabular}

a $-\mathrm{M}+\mathrm{Cr}$ represents no mycorrhizal inoculation in $\mathrm{RC}, 60 \mathrm{mg} \mathrm{kg}^{-1} \mathrm{Cr}(\mathrm{VI})$ addition in $\mathrm{HC}$.

b $+\mathrm{M}+\mathrm{Cr}$ represents mycorrhizal inoculation in $\mathrm{RC}, 60 \mathrm{mg} \mathrm{kg}^{-1} \mathrm{Cr}(\mathrm{VI})$ addition in $\mathrm{HC}$.

c $+\mathrm{M}-\mathrm{Cr}$ represents mycorrhizal inoculation in $\mathrm{RC}$, no $\mathrm{Cr}(\mathrm{VI})$ addition in $\mathrm{HC}$.

d $+\mathrm{M}+\mathrm{F}+\mathrm{Cr}$ represents mycorrhizal inoculation in $\mathrm{RC}, 60 \mathrm{mg} \mathrm{kg}^{-1} \mathrm{Cr}(\mathrm{VI})$ addition in $\mathrm{HC}$, and a $0.45 \mu \mathrm{m}$ acetate filter membrane was used instead of $37 \mu \mathrm{m}$ nylon net.

e $\mathrm{F}(\%)$ represents the frequency of mycorrhizal colonization.

${ }^{\mathrm{f}} \mathrm{M}(\%)$ represents the intensity of the mycorrhizal colonization.

${ }^{\mathrm{g}} \mathrm{A}(\%)$ represents the arbuscule abundance.

${ }^{\text {h }}$ RC represents root compartment.

${ }^{\mathrm{i}} \mathrm{HC}$ represents hyphal compartment. 

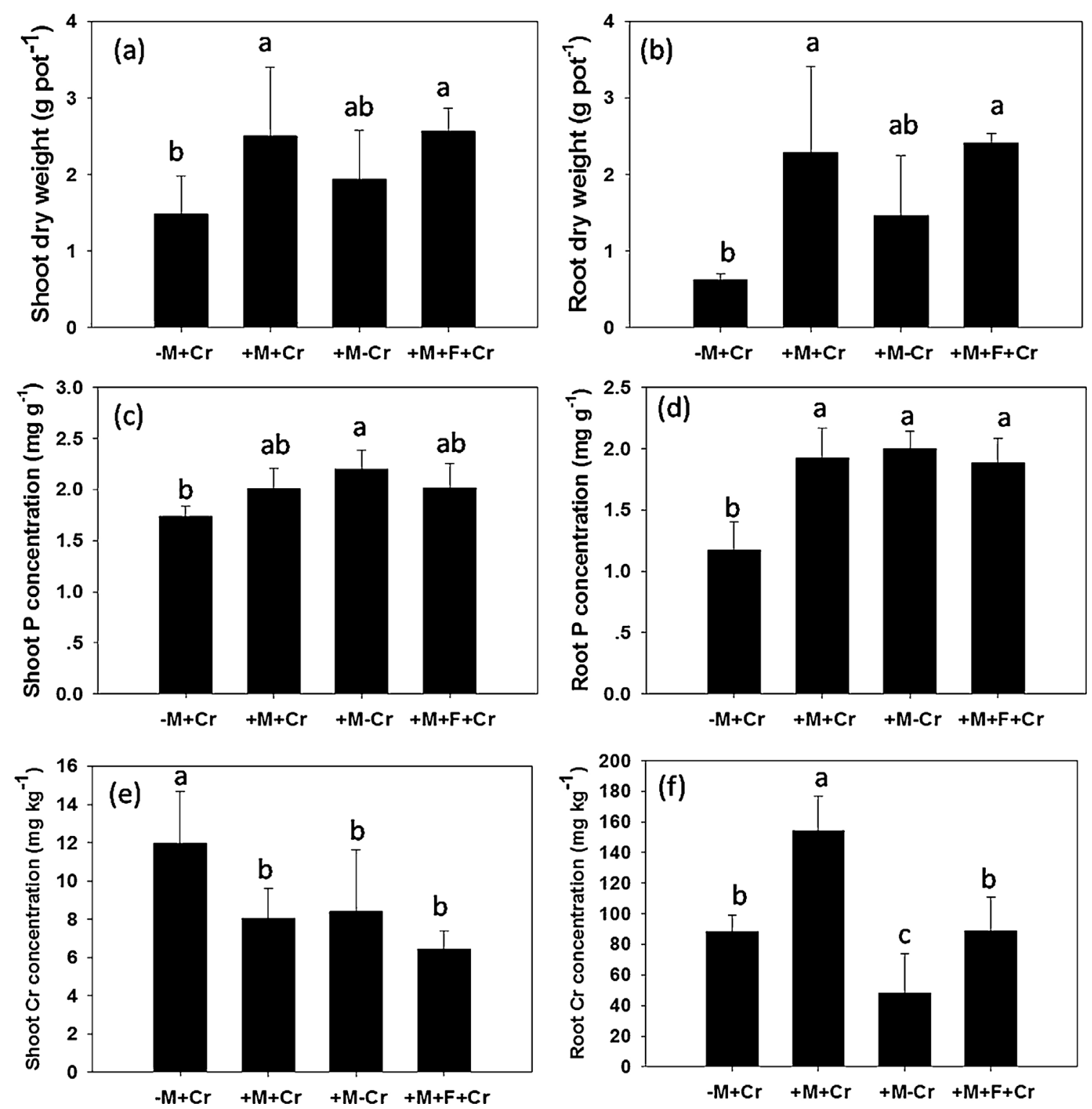

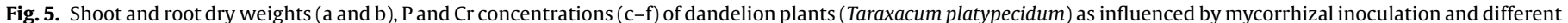

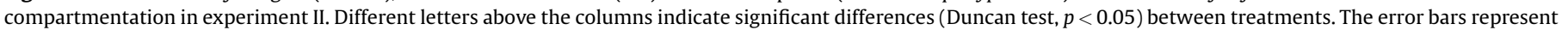

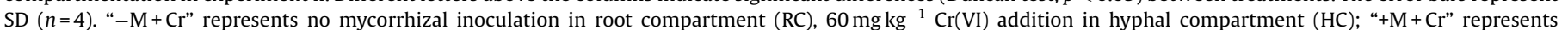

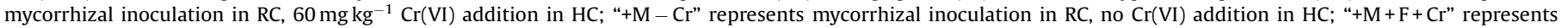
mycorrhizal inoculation in $\mathrm{RC}, 60 \mathrm{mg} \mathrm{kg}^{-1} \mathrm{Cr}(\mathrm{VI})$ addition in $\mathrm{HC}$, and a $0.45 \mu \mathrm{m}$ acetate filter membrane was used instead of $37 \mu \mathrm{m}$ nylon net.

elements, $\mathrm{Cu}$ and $\mathrm{Zn}$ showed different distribution patterns from $\mathrm{Ca}, \mathrm{K}$ and $\mathrm{Fe}$, which may be caused by their chemical properties. $\mathrm{Cu}$ and $\mathrm{Zn}$ are micronutrient elements that can be combined with organic acids for translocation through xylem (Terzano et al., 2008; Collin et al., 2014), while Ca and K are macronutrient elements that can be transported in xylem or phloem (White, 2001; Ahmad and Maathuis, 2014). Fe was mainly accumulated in the cortex, which can be explained by the previous study showing that Fe was likely chelated to the nonproteinogenic amino acid nicotianamine (NA) in the epidermal (Curie et al., 2009).

Once AM symbiosis forms, extensive ERM are developed. These ERM may largely contribute to metal immobilization (Chen et al., 2001; Joner et al., 2000). In order to strictly investigate direct interaction between ERM and $\mathrm{Cr}$, two mycorrhizal treatments one without $\mathrm{Cr}(\mathrm{VI})$ addition to $\mathrm{HC}$ (treatment " $+\mathrm{M}-\mathrm{Cr}$ ") and the other with $0.45 \mu \mathrm{m}$ acetate fiber filter (treatment "+M + F+Cr") were included as controls in experiment II. Similar to our previous study (Chen et al., 2007a; Ren et al., 2015), the mycelium developed well in the inoculated treatments, and passed through the $37 \mu \mathrm{m}$ nylon net to HC, while $0.45 \mu \mathrm{m}$ acetate fiber filter excluded mycelium development in HC. Little hyphae detected in soils of the non-inoculated treatments were probably dead or saprophytic hyphae, and were also considered to be present in the inoculated treatments. Besides, there were no difference among all mycorrhizal treatments for plant shoot and root dry weights (Fig. 5a and b), and thus we successfully diminished the growth dilution effects on $\mathrm{Cr}$ in plants.

The treatment " $+\mathrm{M}+\mathrm{Cr}$ " clearly had a higher root $\mathrm{Cr}$ concentration than other 3 control treatments (Fig. 5f), and this treatment also had the highest root $\mathrm{Cr}$ uptake and total $\mathrm{Cr}$ uptake (Fig. S2), showing that ERM could take up and transport $\mathrm{Cr}$ from distance to mycorrhizal roots. However, there still exists possibility that $\mathrm{Cr}(\mathrm{VI})$ in the $\mathrm{HC}$ may diffuse to $\mathrm{BC}$ and RC. To check this possibility, the soil $\mathrm{Cr}$ speciation in each compartment of all treatments was detected. $\mathrm{Cr}(\mathrm{VI})$, DTPA-extractable $\mathrm{Cr}$, acid-extractable $\mathrm{Cr}$ and reducible $\mathrm{Cr}$ concentrations in $\mathrm{BC}$ and $\mathrm{RC}$ were not significantly different among 
different treatments (Table S2, $p<0.05$ ), which proved that there was no significant diffusion of $\mathrm{Cr}$ from $\mathrm{HC}$ to $\mathrm{RC}$, and thus confirmed that the high $\mathrm{Cr}$ accumulation in mycorrhizal roots of treatment " $+\mathrm{M}+\mathrm{Cr}$ " was due to direct uptake by ERM.

All three mycorrhizal treatments had lower shoot $\mathrm{Cr}$ concentrations than non-mycorrhizal plants, which may result from "growth dilution effects", or $\mathrm{Cr}$ immobilization in mycorrhizal roots. Besides, it is interesting to find that there was no differences in shoot $\mathrm{Cr}$ concentrations among inoculated treatments (Fig. 5e), showing that $\mathrm{Cr}$ uptake by ERM was possibly not translocated from roots to shoots. The lowest TF value of treatments " $+\mathrm{M}+\mathrm{Cr}$ " also confirmed that AM symbiosis retained large quantities of $\mathrm{Cr}$ in roots (or ERM) and little $\mathrm{Cr}$ was translocated to shoots (Fig. S3). AMF itself can retain large quantities of heavy metals (such as $\mathrm{Cu}$, $\mathrm{Zn}, \mathrm{Cd}$ etc) and restrain delivery of these metals to plants (Joner et al., 2000; Chen et al., 2001; Nayuki et al., 2014), which may explain the $\mathrm{Cr}$ immobilization in mycorrhizal roots. In a word, experiment II no doubt proved the direct involvement of AM symbiosis in enhancing plant $\mathrm{Cr}$ tolerance, more exactly ERM can take up and immobilize large quantities of $\mathrm{Cr}$ in mycorrhizal roots.

\section{Conclusions}

In summary, the present work confirms that $\mathrm{P}$ supply in the $\mathrm{Cr}$ (VI) contaminated soil can not improve plant $\mathrm{Cr}$ tolerance as well as AM symbiosis does, and the direct immobilization of $\mathrm{Cr}$ by ERM and mycorrhizal roots plays an important role in plant tolerance to $\mathrm{Cr}$ contamination. However, this does not mean that P aid by AM symbiosis does not contribute to plant $\mathrm{Cr}$ tolerance, as $\mathrm{P}$ uptake and metabolism in mycorrhizal plants are much different from that in non-mycorrhizal plants. Although the present work confirms the uptake and immobilization of $\mathrm{Cr}$ by ERM, whether the $\mathrm{Cr}$ uptake by ERM was actually delivered to plant cells are still unknown and the underlying mechanisms of AMF tolerance to $\mathrm{Cr}$ (VI) needs further investigations. It is necessary to point out that the mechanisms by which AM fungi enhance plant $\mathrm{Cr}$ tolerance may depend on plant and AM fungi species, soil characteristics, etc. Therefore, various plants and AM fungi should also be considered when elucidating how AMF enhance plant $\mathrm{Cr}$ tolerance in the future.

\section{Author's contributions}

S. Wu and B. Chen designed the work. S. Wu, X. Zhang, Z. Wu, T. $\mathrm{Li}, \mathrm{Y}$. Hu and Y. Sun conducted the experiment and acquired the experimental data. Y. Wang prepared the AM fungal inoculum. S. Wu performed the data analysis and prepared the manuscript. B. Chen made critical revision for final submission.

\section{Acknowledgments}

This work was financially supported by National Natural Science Foundation of China (41471219) and National Key Technology R\&D Program, China (2012BAC25B03). The SR $\mu$-XRF was conducted in beamline 4W1B of Beijing Synchrotron Radiation Facility, Institute of High Energy Physics, Chinese Academy of Sciences. Thanks to Dongliang Chen, Wei Xu, Juncai Dong, and Yaxiang Liang for their support in SR $\mu$-XRF analysis and data reduction.

\section{Appendix A. Supplementary data}

Supplementary data associated with this article can be found, in the online version, at http://dx.doi.org/10.1016/j.envexpbot.2015. 08.006.

\section{References}

Ahmad, I., Maathuis, F.J.M., 2014. Cellular and tissue distribution of potassium: physiological relevance, mechanisms and regulation. J. Plant Physiol. 171, 708-714.

Chatterjee, J., Chatterjee, C., 2000. Phytotoxicity of cobalt, chromium and copper in cauliflower. Environ. Pollut. 109, 69-74.

Chen, B.D., Christie, P., Li, X.L., 2001. A modified glass bead compartment cultivation system for studies on nutrient and trace metal uptake by arbuscular mycorrhiza. Chemosphere 42, 185-192.

Chen, B.D., Li, X.L., Tao, H.Q., Christie, P., Wong, M.H., 2003. The role of arbuscular mycorrhiza in zinc uptake by red clover growing in a calcareous soil spiked with various quantities of zinc. Chemosphere 50, 839-846.

Chen, X., Wu, C.H., Tang, J.J., Hu, S.J., 2005. Arbuscular mycorrhizae enhance metal lead uptake and growth of host plants under a sand culture experiment. Chemosphere 60, 665-671.

Chen, B.D., Xiao, X.Y., Zhu, Y.G., Smith, F.A., Xie, Z.M., Smith, S.E., 2007a. The arbuscular mycorrhizal fungus Glomus mosseae gives contradictory effects on phosphorus and arsenic acquisition by Medicago sativa Linn. Sci. Total Environ. 379, 226-234.

Chen, B.D., Zhu, Y.G., Duan, J., Xiao, X.Y., Smith, S.E., 2007b. Effects of the arbuscular mycorrhizal fungus Glomus mosseae on growth and metal uptake by four plant species in copper mine tailings. Environ. Pollut. 147, 374-380.

Collin, B., Doelsch, E., Keller, C., Cazevieille, P., Tella, M., Chaurand, P., Panfili, F., Hazemann, J.L., Meunier, J.D., 2014. Evidence of sulfur-bound reduced copper in bamboo exposed to high silicon and copper concentrations. Environ. Pollut. 187, 22-30.

Curie, C., Cassin, G., Couch, D., Divol, F., Higuchi, K., Le Jean, M., Misson, J., Schikora, A., Czernic, P., Mari, S., 2009. Metal movement within the plant: contribution of nicotianamine and yellow stripe like transporters. Ann. Bot. 103 (1), 1-11.

Davies, F.T., Puryear, J.D., Newton, R.J., Egilla, J.N., Grossi, J.A.S., 2001. Mycorrhizal fungi enhance accumulation and tolerance of chromium in sunflower (Helianthus annuus). J. Plant Physiol. 158, 777-786.

Feng, G., Song, Y.C., Li, X.L., Christie, P., 2003. Contribution of arbuscular mycorrhizal fungi to utilization of organic sources of phosphorus by red clover in a calcareous soil. Appl. Soil Ecol. 22, 139-148.

Jakobsen, I., Abbott, L., Robson, A., 1992. External hyphae of vesicular-arbuscular mycorrhizal fungi associated with Trifolium subterraneum L. New Phytol. 120, 371-380.

Joner, E.J., Leyval, C., 1997. Uptake of Cd-109 by roots and hyphae of a Glomus mosseae Trifolium subterraneum mycorrhiza from soil amended with high and low concentrations of cadmium. New Phytol. 135, 353-360.

Joner, E.J., Briones, R., Leyval, C., 2000. Metal-binding capacity of arbuscular mycorrhizal mycelium. Plant Soil 226, 227-234.

Karandashov, V., Bucher, M., 2005. Symbiotic phosphate transport in arbuscular mycorrhizas. Trends Plant Sci. 10, 22-29.

Katz, S.A., Salem, H., 1994. The Biological and Environmental Chemistry of Chromium. VCH Publishers, New York.

Kuga, Y., Saito, K., Nayuki, K., Peterson, R.L., Saito, M., 2008. Ultrastructure of rapidly frozen and freeze-substituted germ tubes of an arbuscular mycorrhizal fungus and localization of polyphosphate. New Phytol. 178, 189-200.

Kuperman, R.G., Carreiro, M.M., 1997. Soil heavy metal concentrations, microbial biomass and enzyme activities in a contaminated grassland ecosystem. Soil Bio. Biochem. 29, 179-190.

Li, T. Lin, G., Zhang, X., Chen, Y.L., Zhang, S.B., Chen, B.D., 2014. Relative importance of an arbuscular mycorrhizal fungus (Rhizophagus intraradices) and root hairs in plant drought tolerance. Mycorrhiza 24, 595-602.

Lindsay, W., Norvell, W.A., 1978. Development of a DTPA soil test for zinc, iron, manganese, and copper. Soil Sci. Soc. Am. J. 42, 421-428.

Losi, M., Amrhein, C., Frankenberger Jr, W., 1994. Environmental biochemistry of chromium. Rev. Environ. Contam. Toxicol. 136, 91-121.

Mohanty, M., Patra, H.K., 2011. Attenuation of chromium toxicity by bioremediation technology. Rev. Environ. Contam. Toxicol. 210, 1-34.

Nannipieri, P., Giagnoni, L., Landi, L., Renella, G., 2011. Role of phosphatase enzymes in soil. In: Bünemann, E., Oberson, A., Frossard, E. (Eds.), Phosphorus in Action, vol. 26. Springer, Berlin, Heidelberg, pp. 215-243.

Nayuki, K., Chen, B.D., Ohtomo, R., Kuga, Y., 2014. Cellular imaging of cadmium in resin sections of arbuscular mycorrhizas using synchrotron micro X-ray fluorescence. Microbes Environ. 29, 60-66.

Phillips, J.M., Hayman, D.S., 1970. Improved procedures for clearing roots and staining parasitic and vesicular-arbuscular mycorrhizal fungi for rapid assessment of infection. Trans. Br. Mycol. Soc. 55, 158-161.

Qian, H.F., Sun, Z.Q., Sun, L.W., Jiang, Y.F., Wei, Y., Xie, J., Fu, Z.W., 2013. Phosphorus availability changes chromium toxicity in the freshwater alga Chlorella vulgaris. Chemosphere 93, 885-891.

Rauret, G., Lopez-Sanchez, J.F., Sahuquillo, A., Barahona, E., Lachica, M., Ure, A.M., Davidson, C.M., Gomez, A., Luck, D., Bacon, J., Yli-Halla, M., Muntau, H., Quevauviller, P., 2000. Application of a modified BCR sequential extraction (three-step) procedure for the determination of extractable trace metal contents in a sewage sludge amended soil reference material (CRM 483), complemented by a three-year stability study of acetic acid and EDTA extractable metal content. J. Environ. Monit. 2, 228-233.

Ren, B.H., Wu, S.L., Chen, B.D., Wu, Z.X., Zhang, X., 2015. Cr stable isotope fractionation in arbuscular mycorrhizal dandelion and $\mathrm{Cr}$ uptake by extraradical mycelium. Pedosphere 25, 186-191. 
Rillig, M.C., Steinberg, P.D., 2002. Glomalin production by an arbuscular mycorrhizal fungus: a mechanism of habitat modification? Soil Biol. Biochem. 34, 1371-1374.

Rufyikiri, G., Thiry, Y., Wang, L., Delvaux, B., Declerck, S., 2002. Uranium uptake and translocation by the arbuscular mycorrhizal fungus, Glomus intraradices, under root-organ culture conditions. New Phytol. 156, 275-281.

Schachtman, D.P., Reid, R.J., Ayling, S.M., 1998. Phosphorus uptake by plants: from soil to cell. Plant Physiol. 116, 447-453.

Shanker, A.K., Cervantes, C., Loza-Tavera, H., Avudainayagam, S., 2005. Chromium toxicity in plants. Environ. Int. 31, 739-753.

Shrivastava, R., Upreti, R.K., Seth, P.K., Chaturvedi, U.C., 2002. Effects of chromium on the immune system. FEMS Immunol. Med. Microbiol. 34 (1), 1-7.

Singh, H.P., Mahajan, P., Kaur, S., Batish, D.R., Kohli, R.K., 2013a. Chromium toxicity and tolerance in plants. Environ. Chem. Lett. 11, 229-254.

Singh, P.K., Singh, M., Agnihotri, V., Vyas, D., 2013b. Arbuscular mycorrhizal fungi: biocontrol against Fusarium wilt of chickpea. Int. J. Sci. Res. Publ. 3, 1-5.

Skeffington, R., Shewry, P., Peterson, P., 1976. Chromium uptake and transport in barley seedlings (Hordeum vulgare L.). Planta 132, 209-214.

Smith, S.E., Read, D., 2008. Mycorrhizal Symbiosis. Academic Press, San Diego.

Solé, V., Papillon, E., Cotte, M., Walter, P., Susini, J., 2007. A multiplatform code for the analysis of energy-dispersive X-ray fluorescence spectra. Spectrochim. Acta B 62, 63-68.

Spiers, G.A., McGill, W.B., 1979. Effects of phosphorus addition and energy supply on acid phosphatase production and activity in soils. Soil Biol. Biochem. 11, 3-8.

Tappero, R., Peltier, E., Gräfe, M. Heidel, K, Ginder-Vogel, M., Livi, K., Rivers, M., Marcus, M., Chaney, R., Sparks, D., 2007. Hyperaccumulator Alyssum murale relies on a different metal storage mechanism for cobalt than for nickel. New Phytol. 175, 641-654.

Tennant, D., 1975. Test of a modified line intersect method of estimating root length. J. Ecol. 63, 995-1001.

Terzano, R., Al Chami, Z., Vekemans, B., Janssens, K., Miano, T., Ruggiero, P., 2008. Zinc distribution and speciation within rocket plants (Eruca vesicaria $\mathrm{L}$. Cavalieri) grown on a polluted soil amended with compost as determined by XRF microtomography and Micro-XANES. J. Agric. Food Chem. 56, 3222-3231.
Trouvelot, A., Kough, J.L., Gianinazzi-Pearson, V., 1986. Mesure du taux deycorhization VA d'un systeme radiculaire. Recherche de methods d' estimation ayantune ignification fonctionneue. In: Gianinazzi-Pearson, V., Gianinazzi, S. (Eds.), Physiological and Genetical Aspects of Mycorrhizae. INRA Press, Paris, pp. 217-221.

Tyler, G., 1974. Heavy metal pollution and soil enzymatic activity. Plant Soil 41, 303-311.

USEPA, 1996. Alkaline Digestion of Hexavalent Chromium, Method 3060A, Test Methods for Evaluating Solid Waste, Physical/Chemical Methods, SW-846, third update. Office of Solid Waste and Emergency Response, Washington, D.C.

van der Heijden, M.G.A., Klironomos, J.N., Ursic, M., Moutoglis, P., Streitwolf-Engel, R., Boller, T., Wiemken, A., Sanders, I.R., 1998. Mycorrhizal fungal diversity determines plant biodiversity, ecosystem variability and productivity. Nature 396, 69-72.

Wang, F.Y., Lin, X.G., Yin, R., Wu, L.H., 2006. Effects of arbuscular mycorrhizal inoculation on the growth of Elsholtzia splendens and Zea mays and the activities of phosphatase and urease in a multi-metal-contaminated soil under unsterilized conditions. Appl. Soil Ecol. 31, 110-119.

Weiersbye, I.M., Straker, C.J., Przybylowicz, W.J., 1999. Micro-PIXE mapping of elemental distribution in arbuscular mycorrhizal roots of the grass, Cynodon dactylon, from gold and uranium mine tailings. Nucl. Instrum. Methods B 158, 335-343.

White, P.J., 2001. The pathways of calcium movement to the xylem. J. Exp. Bot. 52, $891-899$.

Wu, S.L., Chen, B.D., Sun, Y.Q., Ren, B.H., Zhang, X., Wang, Y.S., 2014. Chromium resistance of dandelion (Taraxacum platypecidum Diels.) and bermudagrass (Cynodon dactylon (linn.) Pers.) is enhanced by arbuscular mycorrhiza in $\mathrm{Cr}(\mathrm{VI})$ contaminated soils. Environ. Toxicol. Chem. 33, 2105-2113.

Zhang, X., Ren, B.H., Wu, S.L., Sun, Y.Q., Lin, G., Chen, B.D., 2015. Arbuscular mycorrhizal symbiosis influences arsenic accumulation and speciation in Medicago truncatula L. in arsenic-contaminated soil. Chemosphere 119 224-230. 